\title{
Radioecological Assessment of the Biosphere Territory "Issyk-Kul"
}

\author{
Djenbaev B.M. ${ }^{1}$, Kaldybaev B.K. ${ }^{2, *}$, Zholbolduev B.T. ${ }^{1}$, Toktoeva T.E. ${ }^{2}$ \\ ${ }^{1}$ Institute Biology \& Pedology, National Academy of Science, Kyrgyz Republic \\ ${ }^{2}$ Ministry of Education and Science, Issyk-Kul State University, Kyrgyz Republic
}

Copyright $\bigcirc 2016$ by authors, all rights reserved. Authors agree that this article remains permanently open access under the terms of the Creative Commons Attribution License 4.0 International License

\begin{abstract}
This article presents the results of the analysis of the environment components (soil, water, air) on the radionuclide which was conducted in the tail deposits, settlers and on adjacent territories. Exposure rate was established on the tail deposit, adjacent territories and coastal sites of the lake Issyk-Kul. Main radioisotopes, total alphaand beta-activity of soil and water, as well as volume concentration of radon were determined in the soil and air above the tail deposit and on adjacent cites of the lake coastal zone. The distribution of radionuclide, alpha- and beta-activity were determined in the lake and stream of Kaji-Sai. Also the assessment of isotopic composition and ratio of uranium-238, uranium-234, thorium-228, radium-228 in the soil and water was given. A map-diagram was made for exposure rate of outer gamma-radiation of Issyk-Kul coastal zones and Kaji-Sai technogenic (man-caused) province.
\end{abstract}

Keywords Issyk-Kul, Province, Tailing, Dump, Biogeochemistry, Exposure Dose, Radionuclide

\section{Actuality}

Issyk-Kul is a protected natural area, which is of international importance, and entered into a worldwide network of biosphere reserves within the framework of the UNESCO program "Man and Biosphere". Issyk-Kul Lake is also an object of national and international tourism. The successful development of tourism in the Issyk-Kul region is favorable climatic conditions. Issyk-Kul intermountain trough, with the north and south is framed by ridges and Terskey- Kungei Ala-Too. A significant part of the basin occupies brackish lake Issyk-Kul. It is located at an altitude of 1609 meters above sea level.

Researches of the professors V. Kowalski and I. Vorotnitsky (1962) was found that the Issyk-Kul intermountain trough is the natural uranium biogeochemical province. This territory is characterized by a high concentration of natural uranium and its daughter products of decay in the earth and ground water. On the other hand, there are also a number of high-level man-made sources of radioactivity - a tailings reprocessing radioactive coal in the village of Kaji-Sai [3, 4, 6, 7, 9, 10, 11].

It is known that the program for sustainable development of the region is linked with the assessment of the radiation exposure of the population as well as the lack of publicly available data in this area, which in turn makes it difficult to create a positive image of the Kyrgyz Republic, in which much of the economic development associated with tourism.

\section{Material and Research Methods}

The dosimeter DKS-96 was used for measuring the radiation of the areas. In accordance with the IAEA regulations, the measurements were made for ground inspection of radiation environment [15].

The gamma spectrometer "Canberra" (Model GX4019 with Genie-2000 software S 502, S501 RUS) was used to determine the concentration of radionuclide isotopic from objects of the environment $[16,17]$.

In order to determine the total alpha and beta activity of the water samples used alpha-beta radiometer UMP-2000 [18].

According to the established guidelines of its registration RaA alpha radiation $\left({ }^{218} \mathrm{Po}\right)$ was conducted method of measurement the radon $\left({ }^{222} \mathrm{Rn}\right)$ in soil and water [19].

\section{Results and Discussion}

Radiometric survey was shown that the level of radiation was relatively low and ranged from 15 to $40 \mathrm{mR} / \mathrm{hr}$ in the Biosphere Territory of the Issyk-Kul. This intermountain was the natural uranium biogeochemical province and there were places with high radiation background. For example, there were high natural background radiations in some 
coastal areas.

\subsection{Lots Coastal Zone of Lake Issyk-Kul with Enhanced Natural Radioactivity}

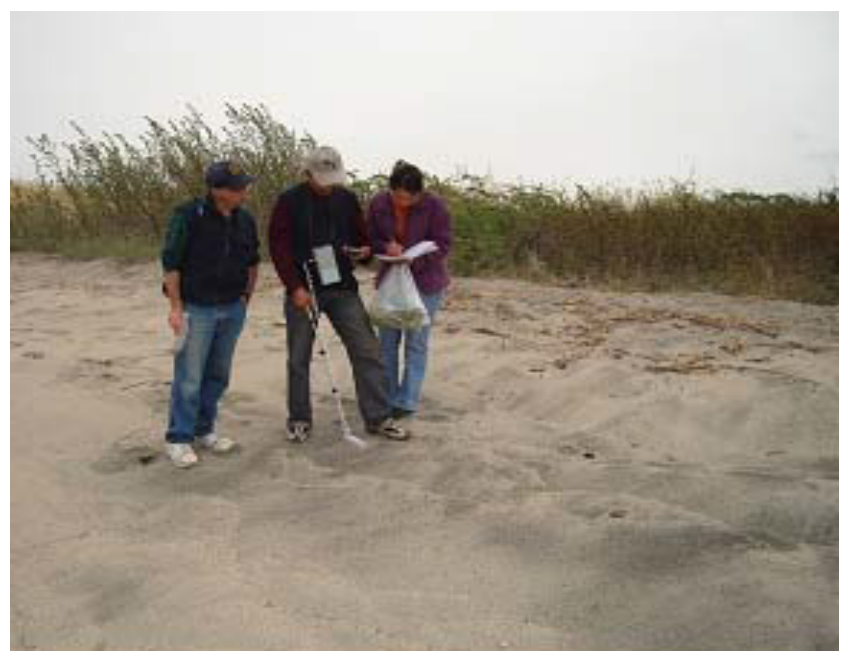

a)

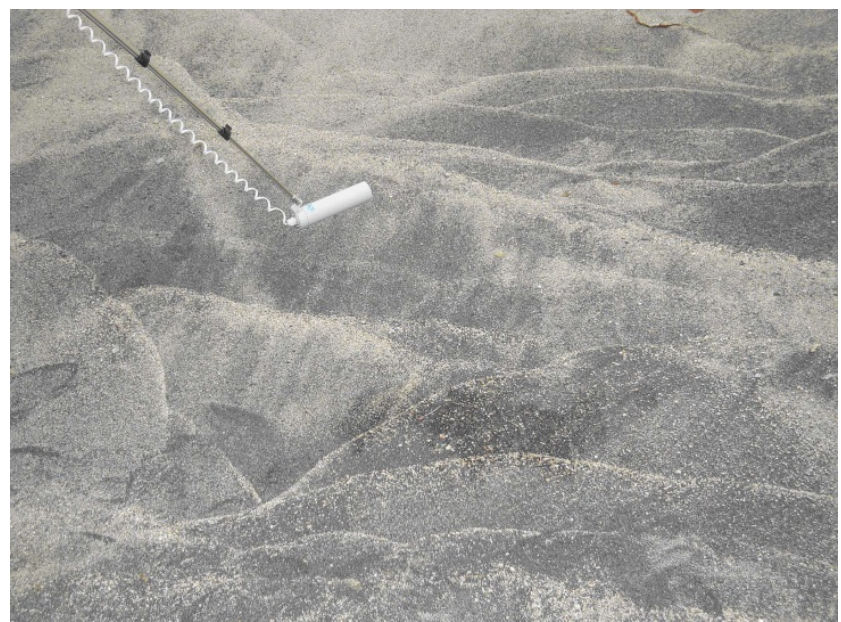

b)

Picture 1. a) Measurements of background radiation in the coastal areas of the village of Ak-Terek and Zhenish. b) thorium sands

We have established high background radiation areas on the southern shore of the lake Issyk-Kul. These sites were in the alluvial deposits of thorium sands of the southern shore of the lake in the villages of Jenish and Ak-Terek, where the dose rate varied from 25 to $52 \mathrm{mR} / \mathrm{hr}$, at least $58-102$, sometimes at certain points comes to $300 \mathrm{mR} / \mathrm{h}$. Using the figures in these two areas at the computer processing of the experimental data (application package "Surfer-12"), we have drawn up a schematic map of the spread of the dose rate of gamma-radiation on the sites of villages of Jenish and Ak-Terek (Fig. 1). Using the named software package allowed us to obtain contours that characterize changes in background radiation area. For a more visual representation of the results beyond the different radiation background changes are presented in a color image, and the corresponding range of background radiation value was close to the figure. Picture 2, there are the results of measurements of background radiation in the villages of Jenish and Ak-Terek and the surrounding areas, received after the computer processing of the results of measurements of gamma about 30 points (points). The results of measurements of background radiation were given in $\mathrm{mR} / \mathrm{hr}$. According to figures the exposure dose of gamma radiation generally varied in the range of $30-60 \mathrm{mR} / \mathrm{hr}$. The little spread areas were with background radiation of $100 \mathrm{mR} / \mathrm{h}$ or less. The highest radioactivity (up to 300 $\mathrm{mR} /$ hour) set in locations with a high concentration of black specks in the sand (Pic. 1).

\subsection{Technogenic Uranium Tailings of Kaji-Sai}

Ministry of Machine Building of the USSR functioned to the processing of uranium ore in the Mining factory of Kaji-Sai from 1948 to 1969, which was subsequently transformed into Electro technical factory. The wastes from the production and industrial machinery were buried near the mining creating tailings damp with a total volume of uranium waste of 400 thousand cubic meters $[1,2,5,6,8,11,13]$. The waste were a mixture of uranium enrichment waste, coal ash from the former power plant, an empty rock and residues of processing of coal ash, which was extracted from uranium in this province. It was clear that the previous attempts to provide a protective coating the tailings was ineffective, because the coating was often destroyed by natural phenomena and the local people, who dig up waste dumps for scrap as a source of income and others. (Pic. 3).

The exposure dose of gamma-radiation was an average of $30-60 \mathrm{mR} / \mathrm{hr}$ on the surface of the ground covered with ash dumps and tailings in Kaji-Say. According to our research, there were the areas with abnormally high levels of exposure dose of $600-1500 \mathrm{mR} / \mathrm{h}$ (up to $15 \mathrm{mSv} / \mathrm{h}$ ). High levels of radioactivity observed in the field of destruction of the protective coating as a result of the excavations, which were made by locals or by natural factors: rain, water and wind erosion. Areas with high level of background radiation (120-200 mR/hr) stored on the territory of the former industrial area, in places of storage of ash brown coal, as well as on the sites of the former extraction production (Picture 3 ).

According to the results of measurements in the field of destruction of the protective coating tailing, it was drawn the diagram of the spatial distribution of the dose rate of gamma radiation. This methodological approach was used in the studied areas before and after the restoration of the protective layer of the Ministry of Emergency Situations of the Kyrgyz Republic (Picture 4).

Table 1. There are the states of the province: the river bed in the area of the tailings, sediment 1-3, the industrial site and the area around the tailings waste up to $200 \mathrm{~m}$, the exposure dose to the background level or a little higher, but lower than adopted norm in the Kyrgyz Republic (60 mR / h) (Picture 4). 
The sediment was below the tailings, but the condition was satisfactory. The level of background radiation varied from 22 to $40 \mathrm{mR} / \mathrm{h}$, there was below the permissible level. We also carried out measurements in the coastal zone of lake Issyk-Kul (plots - Balykchy, Cholpon-Ata, Ortho-Oruktu; Tup, Jeti-Oguz, Ak-Terek; Jenish; Kaji-Sai; mouth of the 5 rivers - Tup, Jyrgalan, Jeti-Oguz, Ak-Terek and Barskon). The power of natural background radiation by gamma radiation of the coastal zone of the lake was an average of 17 to $25 \mathrm{mR} / \mathrm{h}$ and up to $40 \mathrm{mR} / \mathrm{h}$ in some areas. The level of background radiation raised to $40 \mathrm{mR} / \mathrm{h}$ with a slightly increased radioactivity in some places as the distance from the lake towards the mountain slopes, especially in mountainous areas and gorges, which are based on rock, granite, fine their fragments and red sand (Table 2). The mostly mud sediments with characteristic brilliance slyudennym giving increased radiation background in the small areas of the coastal zone of Lake Issyk-Kul (Tosor 40-50 mR/h, Kaji-Sai - 32-40 mR/h, the Torah-Aygyr - 30 $\mathrm{mR} / \mathrm{h}$, Tamchi $-40-50 \mathrm{mR} / \mathrm{h}$ and al.) According to the results of measurements of background radiation of natural and man-made sites of the coastal zone of the Lake Issyk-Kul, it was drawn sketch map of the exposure dose of external gamma radiation on the territory of Issyk-Kul region (Picture 5).

The total alpha and beta activity of the soil was shown in Table 3. There was the total activity of alpha- and beta-emitting radionuclide in the coastal zone of the sandy soil and below the soil is in comparison with other types on the territory of natural and man-made uranium province of Kaji-Sai.

It is known that the concentration of organic component increased in the soil. It was reduced the degree of leaching of $\alpha$-, $\beta$ - emitting radionuclide. The results showed that the total $\Sigma \alpha$ - activity in the sand fraction was 10 times lower than the clay fraction.
The isotopic composition of the soil. According to our research the specific activity of uranium and other natural radionuclide was not high in the soil cover except technologically contaminated sites. The specific activity of natural radionuclide was higher on the top soil than the lower layers, and the specific activity was 3 - 20 times higher in the thorium sends of the villages of Ak-Terek and Jenish (Table 5.). We had also studied the present state of the isotopic composition of sediment on the horizons (the soils were collected from the sediments, Pic. 7) shown in-Table 8. There were the level of isotope is $\mathrm{Pb}-210$ relatively higher on the sediment-2 as well as compared with other studied isotopes of radionuclide in the upper layer of the sediment (up to $0-30 \mathrm{~cm}$ ) and in the lower layers is slightly reduced, but it increases the level of $\mathrm{U}-238100$ to $150 \mathrm{~Bq} / \mathrm{kg}$.

In the sediment- 3 to $\mathrm{Pb}-210$ occurred to the same pattern as in the sediment- 2, and the isotopic composition of U-238 sharply increased on the second layer of soil from 360 to 540 $\mathrm{Bq} / \mathrm{kg}$ and below the concentration level decreased sharply to $160 \mathrm{~Bq} / \mathrm{kg}$. The high level of concentration of other isotopes was not found. We had also studied the total radioactivity of the soil adjacent territory of Kaji-Sai tailings and ${ }^{238} \mathrm{U},{ }^{234} \mathrm{U},{ }^{228} \mathrm{Th},{ }^{228} \mathrm{Ra},{ }^{230} \mathrm{Th},{ }^{210} \mathrm{~Pb},{ }^{226} \mathrm{Ra}$ and ${ }^{40} \mathrm{~K}$ (tab. 5). The table shows that if we compared with the concentration of ${ }^{228} \mathrm{Th}$ and ${ }^{228} \mathrm{Ra}$ at the same level, and ${ }^{40} \mathrm{~K}$ in all investigated areas in the tailings area in relation to the ${ }^{228} \mathrm{Th}$ and ${ }^{228} \mathrm{Ra}$ from an average of 10 to 15 times more. ${ }^{230} \mathrm{Th}$ is found only on the 3 areas and their concentration are at a high level, especially in the ground, on the surface in the vicinity of industrial area (spot $140 \mathrm{mR} / \mathrm{h})-15513 \pm 1265$. Concentrations of ${ }^{210} \mathrm{~Pb}$ and ${ }^{226} \mathrm{Ra} 1-3$ and 7 sites are in average at the same level, and it differs to 2-3 times, and the maximum accumulation observed at $4-6$ portions. ${ }^{210} \mathrm{~Pb}$ and ${ }^{226} \mathrm{Ra}$ activity is quite high $\left({ }^{210} \mathrm{~Pb}-12121 \pm 204\right.$ and ${ }^{226} \mathrm{Ra}-$ $10643 \pm 75)$ in the soil on the surface near the industrial area and the tailings, ash from the plant (spot $140 \mathrm{mR} / \mathrm{h}$ ). 


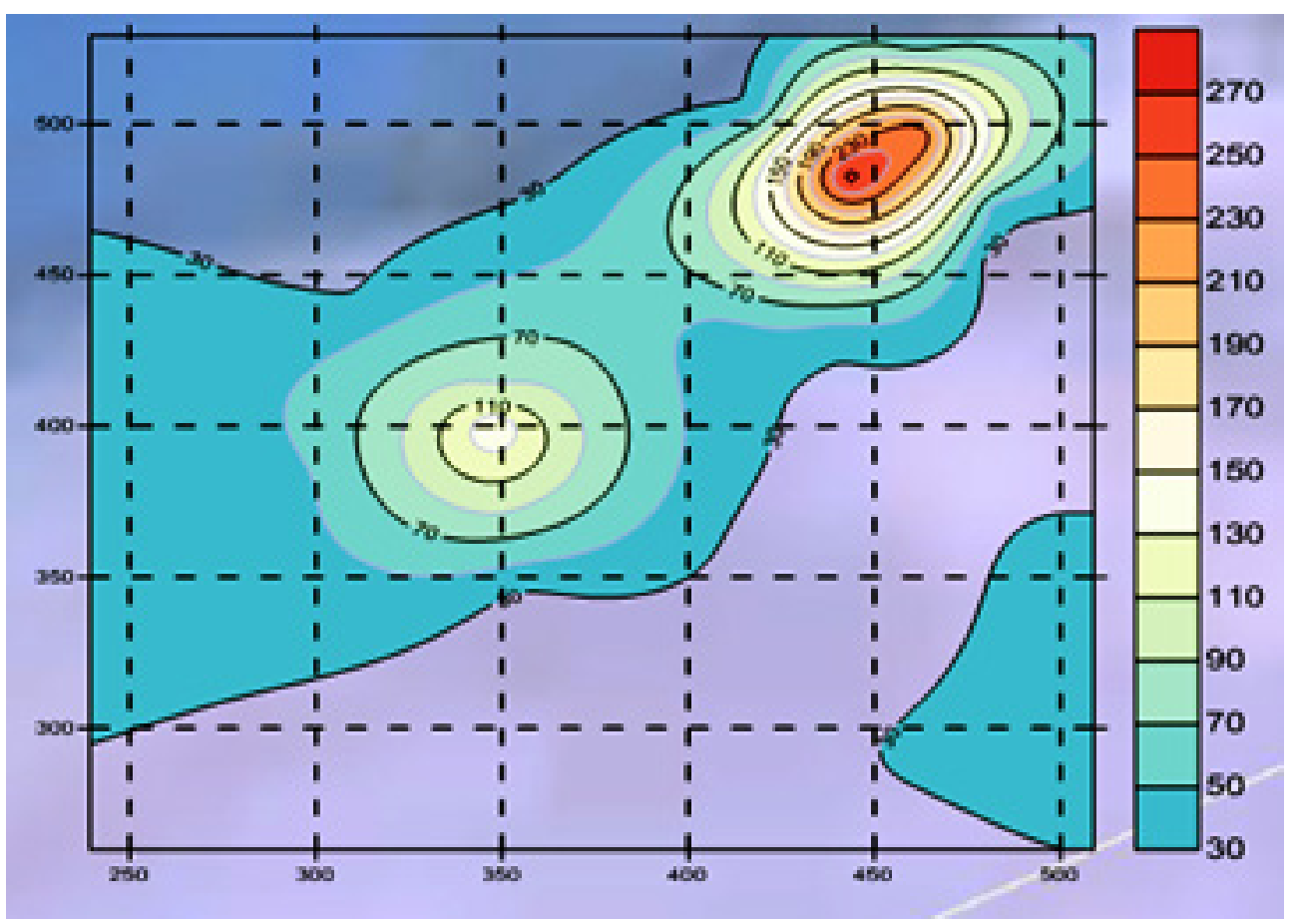

Picture 2. Scheme of the spatial dose distribution gamma radiation in the areas villages Zhenish and Ak-Terek (mR/h)
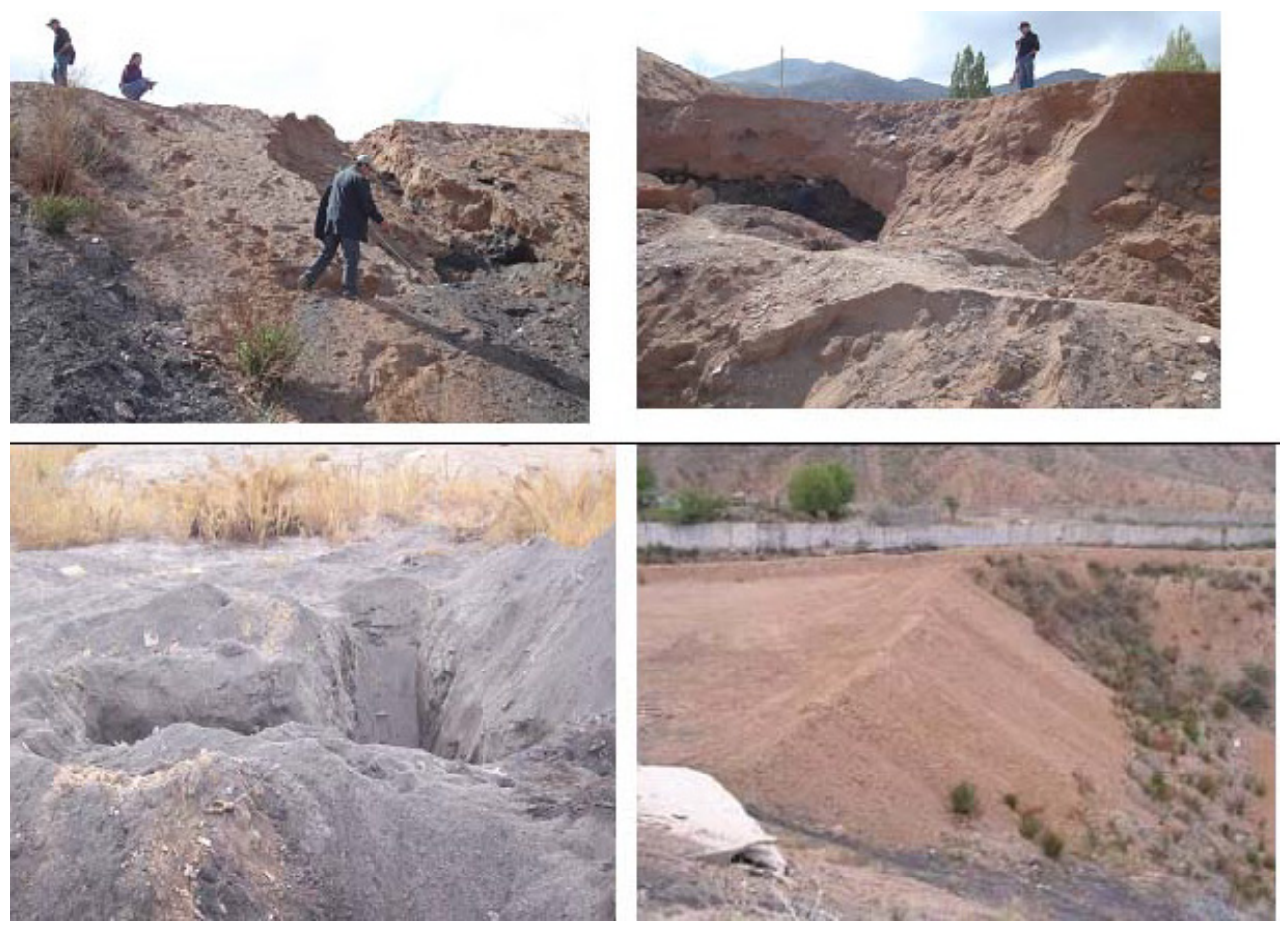

Picture 3. The current state of the tailings 


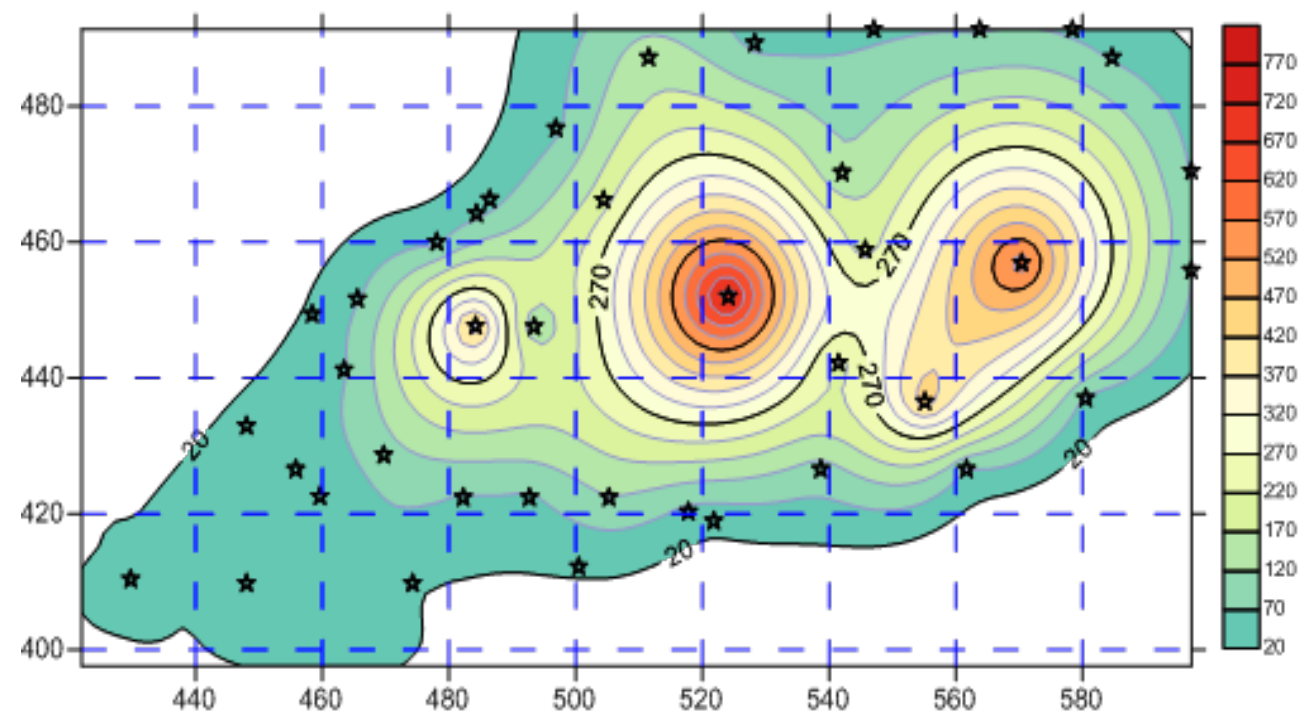

a)

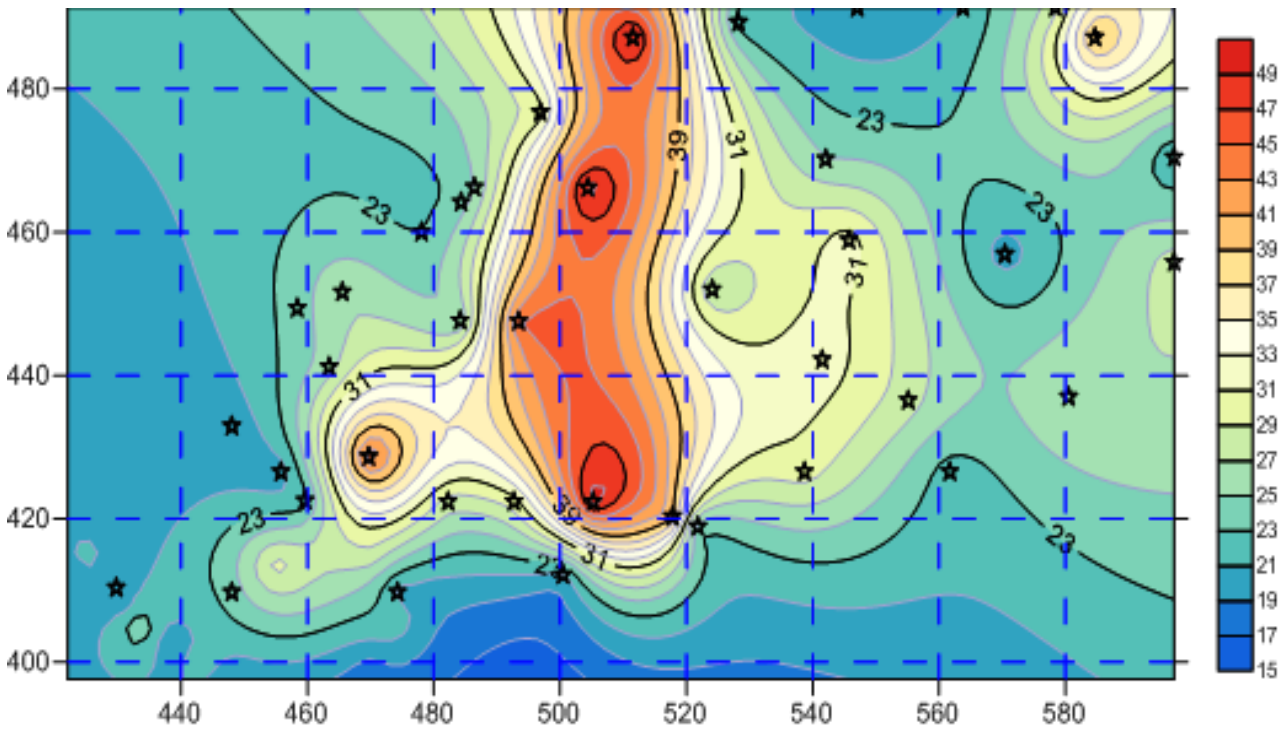

b)

Note - selection $\star$-point

Picture 4. a) In the field of protective coating violations; b) After restoring the protective layer (mR/h)

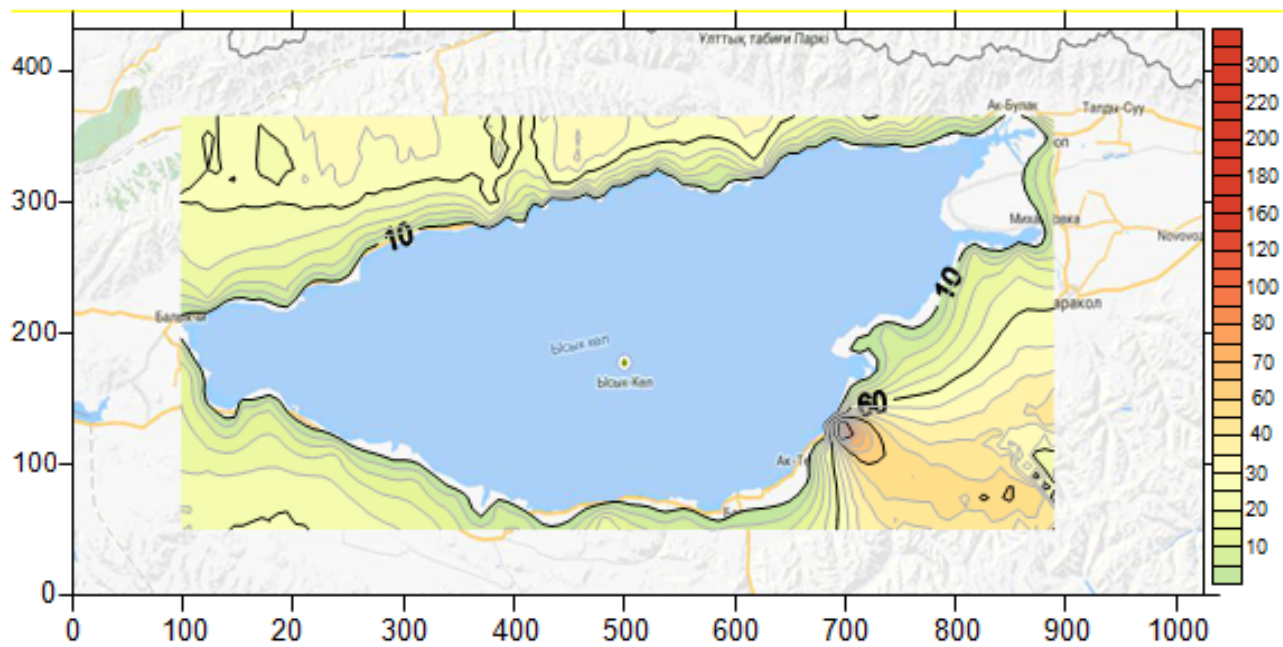

Figure 5. Schematic map of the exposure dose of external gamma radiation in the coastal zones of the lake Issyk-Kul (mR/h) 


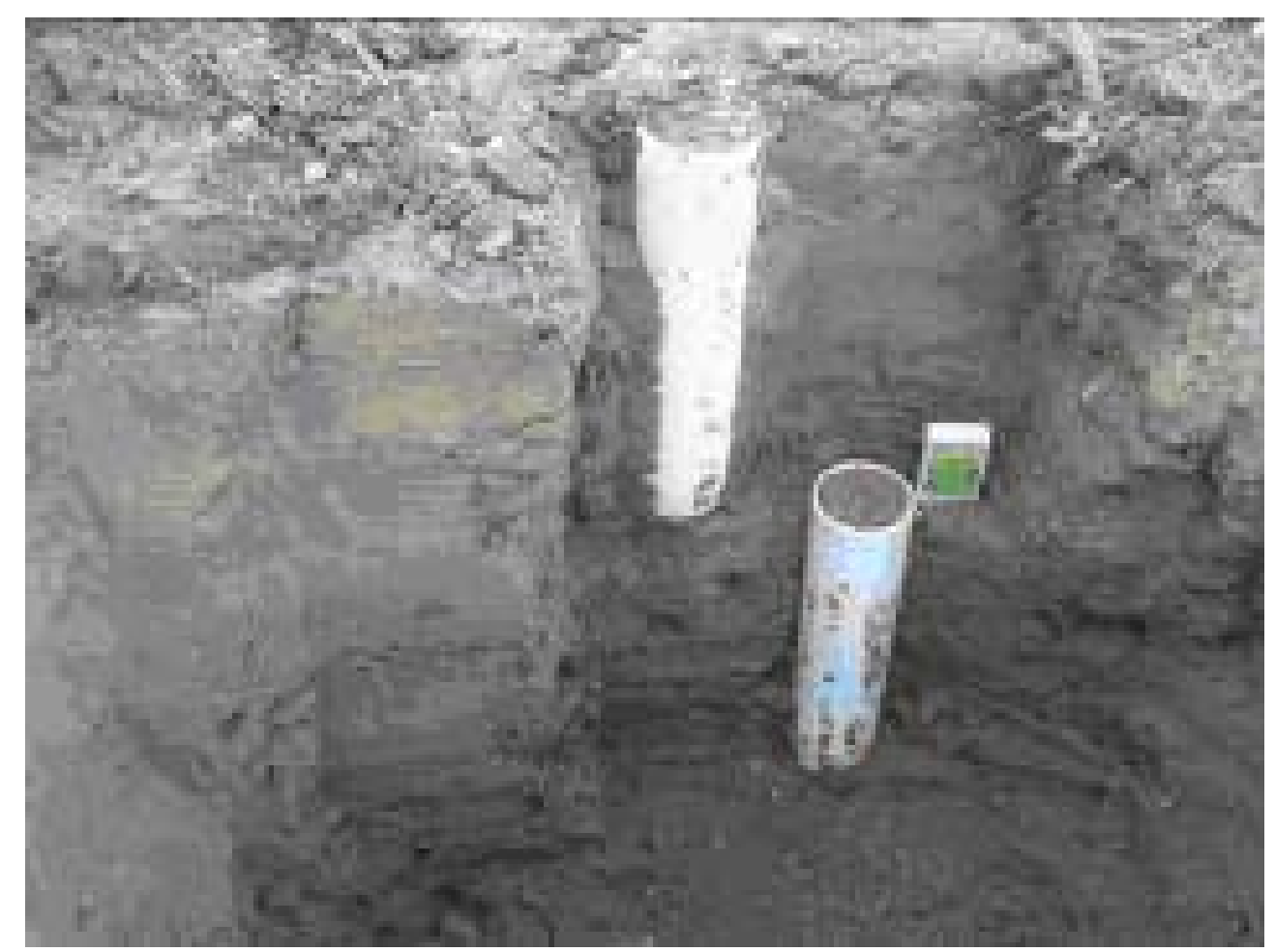

Picture 6. Sampling soil from the sediments

Table 1. The level of background radiation in the natural technology province of Kaji-Sai

\begin{tabular}{|c|c|c|}
\hline Location & On the surface of the soil (mR/hr) & $\begin{array}{c}\text { From the soil surface at a height } \\
1 \mathrm{~m}(\mathrm{mR} / \mathrm{hr})\end{array}$ \\
\hline The river bed in the area of the tailings & $20-35$ & $30-28$ \\
\hline Sediment № 1 & $20-35$ & 30 \\
\hline Sediment № 2 & $20-35$ & 25 \\
\hline Sediment № 3 & $18-30$ & $20-35$ \\
\hline Processing of coal slag plant & $20-45$ & $20-37$ \\
\hline Tailings & $20-40$ & 20 \\
\hline Above the tailings (200 m) & $22-28$ & 25 \\
\hline Above the tailings (1 km mountain side) & $27-34$ & $12-20$ \\
\hline Living sector & $19-25$ & \\
\hline
\end{tabular}


Table 2. The exposure dose rate of gamma radiation coastal areas of the lake Issyk-Kul

\begin{tabular}{|c|c|c|c|}
\hline № & \multicolumn{2}{|c|}{ The place of measurement } & Exposure dose $(\mathrm{mR} / \mathrm{h})$ \\
\hline 1 & c.Balykchy (north-east) & $10-30 \mathrm{~m}$ from the lake & $13-27$ \\
\hline 2 & c.Cholpon-Ata & $\begin{array}{l}\text { Biological Station } \\
20 \mathrm{~m} \text { from the lake, } \\
50 \mathrm{~m} \text { from the lake }\end{array}$ & $\begin{array}{l}21-27 \\
23-32\end{array}$ \\
\hline \multirow[b]{2}{*}{3} & \multirow[b]{2}{*}{ from v.Ortho-Oruktu } & $300 \mathrm{~m}$ from the lake & $35-41$ \\
\hline & & $\begin{array}{c}\text { Hot spring, } \\
500 \mathrm{~m} \text { from the lake }\end{array}$ & $33-35$ \\
\hline 4 & Tup bay & 10-20 $\mathrm{m}$ from r.Tup & $17-22$ \\
\hline 5 & $\begin{array}{l}\text { from v.Mikhailovka } \\
\text { (the bridge) }\end{array}$ & 5-20 $\mathrm{m}$ from r.Zhyrgalan & $23-30$ \\
\hline 6 & $\begin{array}{l}\text { p. Jets-Oguz } 800 \mathrm{~m} \\
\text { from the lake }\end{array}$ & $\begin{array}{l}\text { r.Dzhety-Oguz, } \\
10-20 \mathrm{~m} \text { from the river }\end{array}$ & $27-36$ \\
\hline 7 & v.Ak-Terek & $10-30 \mathrm{~m}$ from the lake & $52-96$ \\
\hline \multirow{2}{*}{8} & \multirow{2}{*}{ v. Jenish } & $10-30 \mathrm{~m}$ from the lake & $58-102$ \\
\hline & & $10-30 \mathrm{~m}$ from the lake & $230-390$ \\
\hline 9 & v. Kaji-Sai & $20-40 \mathrm{~m}$ from the lake & $21-40$ \\
\hline 10 & Koltsovki bay & $20-30 \mathrm{~m}$ from the lake & $21-32$ \\
\hline 11 & Bar-Bulak (Mountains Source) & $1200 \mathrm{~m}$ from the lake & $20-42$ \\
\hline
\end{tabular}

Table 3. The total activity of alpha- and beta-emitting radionuclide $(\Sigma \alpha$ and $\Sigma \beta)$ in different types of soil, Bq/kg.

\begin{tabular}{|c|c|c|c|c|}
\hline & $\begin{array}{c}\text { Sandy } \\
\text { the soil } \\
(\text { Coastal })\end{array}$ & Light brown & The mountain-valley light brown & $\begin{array}{c}\text { The mountain-valley } \\
\text { chestnut }\end{array}$ \\
\hline$\Sigma \alpha$ & $180 \pm 60$ & $260 \pm 40$ & $280 \pm 100$ & $330 \pm 80$ \\
\hline$\Sigma \beta$ & $340 \pm 30$ & $480 \pm 50$ & $530 \pm 50$ & $560 \pm 40$ \\
\hline
\end{tabular}

Table 4. The total activity of alpha- and beta-emitting radionuclide

\begin{tabular}{|c|c|c|c|}
\hline \multicolumn{2}{|c|}{ Sand fraction } & \multicolumn{2}{c|}{ Clay fraction } \\
\hline$\Sigma \alpha$ & $\Sigma \beta$ & $\Sigma \alpha$ & $\Sigma \beta$ \\
\hline $100 \pm 50$ & $360 \pm 50$ & $930 \pm 260$ & $980 \pm 70$ \\
\hline
\end{tabular}

Table 5. Background values of alpha-active isotopes in the soil around the lake Issyk-Kul.

\begin{tabular}{|c|c|c|c|c|c|c|}
\hline \multirow{2}{*}{ Places } & \multirow{2}{*}{$\begin{array}{c}\text { Layer } \\
\mathrm{cm}\end{array}$} & \multicolumn{5}{|c|}{ Active isotopes in the soil, Bq/kg } \\
\cline { 3 - 7 } & $0-5$ & $70,8 \pm 12,1$ & $35,8 \pm 4$ & $120,8 \pm 10$ & $37,8 \pm 2,3$ & $35,8 \pm 2,3$ \\
\hline \multirow{3}{*}{ Kara-Oi } & $5-10$ & $50,8 \pm 6,1$ & $38,8 \pm 3,4$ & $63,8 \pm 12$ & $47,8 \pm 1,3$ & $65,8 \pm 2,5$ \\
\cline { 2 - 7 } & $10-15$ & $42,5 \pm 1,1$ & $36,8 \pm 2,4$ & $50,8 \pm 7,2$ & $45,7 \pm 1,8$ & $52,8 \pm 3,5$ \\
\cline { 2 - 7 } & $15-20$ & $52,5 \pm 6,5$ & $46,8 \pm 3,2$ & $50,2 \pm 7,0$ & $49,7 \pm 1,9$ & $53,8 \pm 4,5$ \\
\hline \multirow{3}{*}{\begin{tabular}{c} 
Kichi-Ak-Suu \\
\cline { 2 - 7 }
\end{tabular}} & $0-5$ & $71,8 \pm 14,1$ & $51,8 \pm 3,4$ & $88,8 \pm 12$ & $67,8 \pm 3,3$ & $72,8 \pm 2,5$ \\
\cline { 2 - 7 } & $5-10$ & $52,8 \pm 4,5$ & $43,2 \pm 3,1$ & $72,8 \pm 10$ & $43,2 \pm 3,2$ & $58,8 \pm 12,5$ \\
\hline $\begin{array}{c}\text { Ak-Terek } \\
\text { (thorium } \\
\text { sands) }\end{array}$ & $10-20$ & $54,8 \pm 7,5$ & $45,2 \pm 3,2$ & $68,8 \pm 7,0$ & $63,2 \pm 3,8$ & $64,8 \pm 7,5$ \\
\hline
\end{tabular}


Table 6. Activities of radionuclide in the soil near the tailing of Kaji-Sai

\begin{tabular}{|c|c|c|c|c|c|c|c|c|c|c|c|c|c|c|c|c|}
\hline \multirow{2}{*}{ Place of sampling } & \multicolumn{2}{|c|}{$\mathrm{U}-238$} & \multicolumn{2}{|c|}{$\mathrm{U}-234$} & \multicolumn{2}{|c|}{ Th-230 } & \multicolumn{2}{|c|}{$\mathrm{Ra}-226$} & \multicolumn{2}{|c|}{$\mathrm{Pb}-210$} & \multicolumn{2}{|c|}{ Th-228 } & \multicolumn{2}{|c|}{$\mathrm{Ra}-228$} & \multicolumn{2}{|c|}{$\mathrm{K}-40$} \\
\hline & $\mathrm{Bq} / \mathrm{kg}$ & \pm & $\mathrm{Bq} / \mathrm{kg}$ & \pm & $\mathrm{Bq} / \mathrm{kg}$ & \pm & $\mathrm{Bq} / \mathrm{kg}$ & \pm & $\mathrm{Bq} / \mathrm{kg}$ & \pm & $\mathrm{Bq} / \mathrm{kg}$ & \pm & $\mathrm{Bq} / \mathrm{kg}$ & \pm & $\mathrm{Bq} / \mathrm{kg}$ & \pm \\
\hline The slope in front of the sump 1 & 105 & 6 & 5 & 3 & MDA & - & 134 & 9 & 146 & 10 & 49 & 1 & 51 & 6 & 871 & 24 \\
\hline $\begin{array}{l}\text { The bottom stream from the area of the } \\
\text { settler }\end{array}$ & 126 & 7 & 6 & 4 & MDA & - & 98 & 3 & 107 & 11 & 73 & 3 & 56 & 7 & 743 & 24 \\
\hline Industrial site, ash dumps & 157 & 14 & MDA & & MDA & - & 117 & 9 & 114 & 14 & 54 & 5 & 44 & 5 & 305 & 23 \\
\hline Industrial site, a spot $140 \mathrm{mR} / \mathrm{h}$ & 3152 & 148 & 154 & 44 & 15513 & 1265 & 10643 & 75 & 12121 & 204 & 46 & 8 & MDA & & 899 & 187 \\
\hline Ash from Thermal power plant №1 & 2483 & 160 & 120 & 39 & MDA & 412 & 2551 & 182 & 2674 & 157 & 82 & 9 & 105 & 50 & 514 & 213 \\
\hline Ash in the territory of shop №2 & 3736 & 174 & 184 & 44 & 3183 & 228 & 3383 & 228 & 3462 & 172 & 42 & 4 & 53 & 27 & 443 & 78 \\
\hline Sediment №1, the cut $70 \mathrm{~cm}$ & 2338 & 353 & 113 & 21 & 5403 & 960 & 294 & 29 & 251 & 14 & 63 & 5 & 69 & 10 & 333 & 34 \\
\hline
\end{tabular}

Table 7. The total $\alpha$ - and $\beta$ - activity of radionuclide in the water of the river and lake.

\begin{tabular}{|c|c|c|}
\hline \multirow{2}{*}{ Place of sampling } & \multicolumn{2}{|c|}{ The total activity of radionuclide $(\mathrm{Bq} / \mathrm{l})$} \\
\hline & $\alpha$ - activity & $\beta$ - activity \\
\hline Karakol river & $0,25 \pm 0,02$ & $0,13 \pm 0,01$ \\
\hline Tup river & $0,23 \pm 0,02$ & $0,12 \pm 0,01$ \\
\hline Jyrgalan river & $0,22 \pm 0,02$ & $0,11 \pm 0,01$ \\
\hline Kichi Ak-Suu river & $0,20 \pm 0,02$ & $0,10 \pm 0,01$ \\
\hline lake Issyk-Kul (the village of Kara-Oy) & $1,80 \pm 0,17$ & $1,04 \pm 0,1$ \\
\hline lake Issyk-Kul (the village Ak-Terek) & $0,60 \pm 0,05$ & $0,44 \pm 0,03$ \\
\hline lake Issyk-Kul (Balykchy city) & $0,95 \pm 0,05$ & $0,65 \pm 0,05$ \\
\hline lake Issyk-Kul (the village Kaji-Sai) & $1,67 \pm 0,17$ & $0,88 \pm 0,09$ \\
\hline
\end{tabular}

Table 8. Levels of alpha activity in the drainage water around the tailings of Kaji-Sai as well as in the water of lake Issyk-Kul (data shown in Bq/1 (+ 10\%))

\begin{tabular}{|c|c|c|c|c|}
\hline Place of sampling & $\begin{array}{c}{ }^{234+238} \mathrm{U}, \\
\mathrm{Bq} / 1\end{array}$ & $\begin{array}{c}\alpha \text { - activity } \\
\text { Bq/1 }\end{array}$ & ${ }^{234} \mathrm{U} /{ }^{238} \mathrm{U}$ & $\begin{array}{l}{ }^{226} \mathrm{Ra} \\
\mathrm{Bq} / 1\end{array}$ \\
\hline The stream from the tailings area in the sediment №1 (after the raining) & 4,21 & 4,5 & 1,49 & 0,007 \\
\hline The stream from the tailings area in the sediment №2 (after the raining) & 10,0 & 10,2 & 1,30 & 0,005 \\
\hline Water from a spring comes under the tailing damp of Kaji-Sai & 6,4 & 6.7 & 1,52 & 0,025 \\
\hline Lake Issyk-Kul, water from the mouth of the river near the tailings & 1,67 & 1,69 & 1,43 & 0,015 \\
\hline Lake Issyk-Kul in the village of Kaji-Sai & 1,19 & 1,20 & 1,30 & 0,014 \\
\hline Lake Issyk-Kul in the village of Ak-Terek & 0,56 & 1,16 & 0,60 & 0,018 \\
\hline Lake Issyk-Kul, the city of Cholpon-Ata & 0,79 & 0,80 & 1,13 & 0,010 \\
\hline
\end{tabular}


Table 9. The level of ${ }^{222} \mathrm{Rn}$ in the soil covers in the coastal areas of the lake Issyk-Kul

\begin{tabular}{|c|c|c|}
\hline № & Place of sampling & $\mathrm{mBq} /\left(\mathrm{m}^{2} \times \mathbf{s}\right)$ \\
\hline 1 & Balykchy city (north-east from the coast to $20 \mathrm{~m})$ & $17,60+/-2,1$ \\
\hline 2 & Cholpon-Atacity(Biological station area) & $30,61+/-3,2$ \\
\hline 3 & Oruktu village (200 m from the shore) & $15,80+/-1,6$ \\
\hline 4 & Oruktu village (hot spring area) & $24,24+/-2,2$ \\
\hline 5 & Tup bay & $11,50+/-0,8$ \\
\hline 6 & Mikhailovka village near the bridge & $14,35+/-2,1$ \\
\hline 7 & Ak-Terek village & $19,20+/-1,7$ \\
\hline 8 & Jenish village (from slopes $60 \mathrm{~m})$ & $18,37+/-2,2$ \\
\hline 9 & Kaji-Sai village (100 $\mathrm{m}$ from the shore) & $19,86+/-3,1$ \\
\hline 10 & Bar-Bulak village (hot spring) & $28,48+/-2,6$ \\
\hline
\end{tabular}

Table 10. The concentration of alpha-active aerosols in the atmosphere of industrial zone around the tailings, as well as a residential area of Kaji-Sai and the city of Cholpon-Ata

\begin{tabular}{|c|c|c|c|c|c|c|c|c|c|c|c|}
\hline \multirow{3}{*}{$\begin{array}{l}\text { Sampling points } \\
\text { aerosol }\end{array}$} & \multirow{3}{*}{$\begin{array}{l}\text { volume } \\
\text { pumping } \\
\text { air }\left(\mathrm{m}^{3}\right)\end{array}$} & \multicolumn{10}{|c|}{ The concentration of radionuclide, $10^{-5} \mathrm{~Bq} / \mathrm{m}^{3}$} \\
\hline & & \multicolumn{2}{|c|}{${ }^{238} \mathrm{U}$} & \multicolumn{2}{|c|}{${ }^{226} \mathrm{Ra}$} & \multicolumn{2}{|c|}{${ }^{210} \mathrm{~Pb}$} & \multicolumn{2}{|c|}{${ }^{228} \mathrm{Th}$} & \multicolumn{2}{|c|}{${ }^{7} \mathrm{Be}$} \\
\hline & & & $+/-$ & & $+/-$ & & $+/-$ & & $+/-$ & & $+/-$ \\
\hline Uranium-sediment-1 & 275 & 3,2 & 1,8 & 3,0 & 0,8 & 75,5 & 2,6 & 1,5 & 0,6 & 179 & 6 \\
\hline Industrial area & 384 & 2,2 & 1,0 & 2,1 & 0,5 & 49,6 & 1,8 & 1,1 & 0,4 & 197 & 7 \\
\hline $\begin{array}{c}\text { Living sector } \\
\text { village Kaji-Sai }\end{array}$ & 220 & 3,5 & 1,5 & 3,8 & 0,8 & 103,9 & 10,1 & 1,9 & 0,6 & 210 & 22 \\
\hline $\begin{array}{c}\text { Cholpon-Atacity, north } \\
\text { coast }\end{array}$ & 306 & 2,6 & 1,2 & 2,7 & 0,5 & 84,3 & 4,8 & 1,4 & 0,6 & 334 & 18 \\
\hline
\end{tabular}

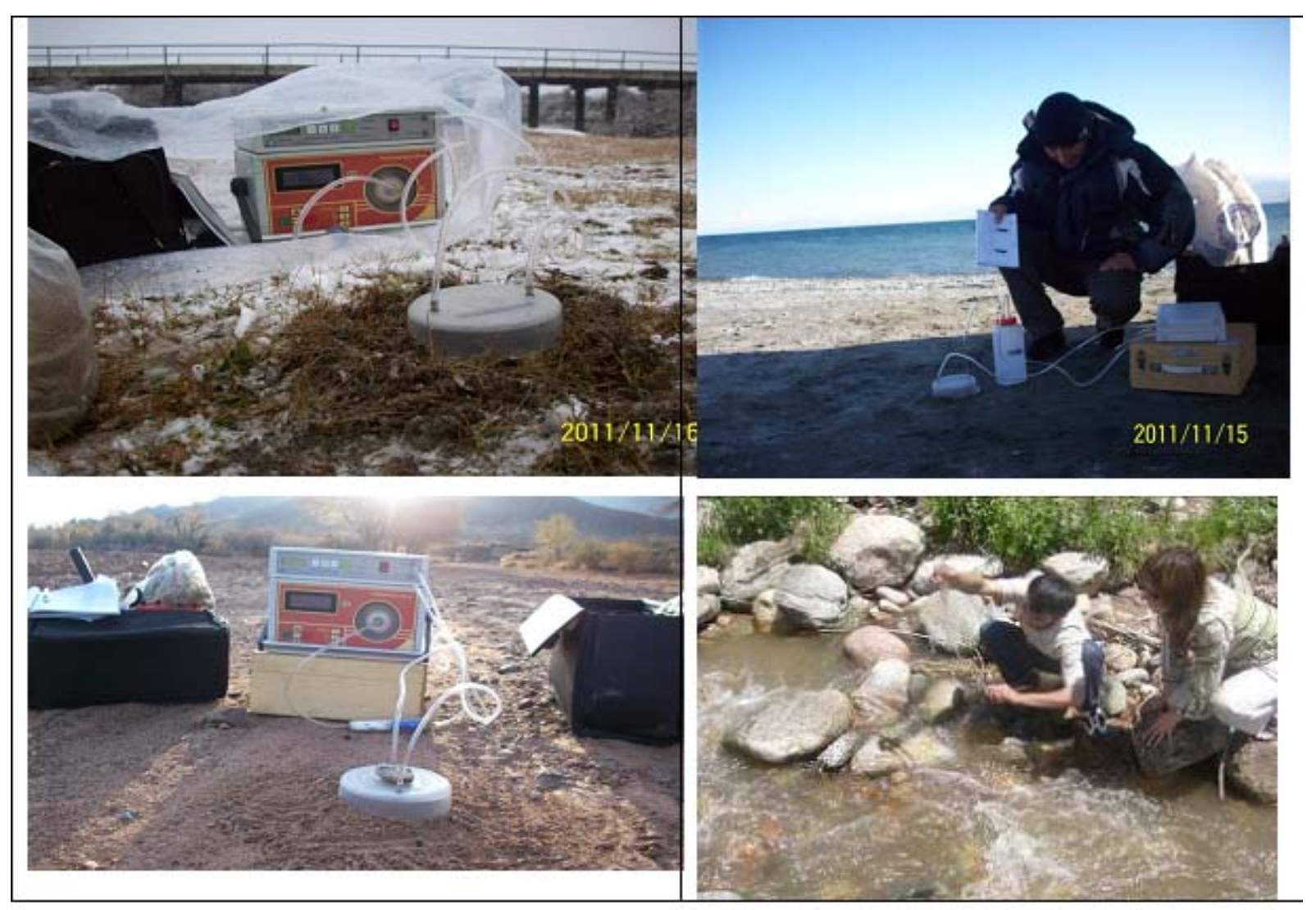

Picture 10. The process of measurements ${ }^{222} \mathrm{Rn}$ in the soil cover 


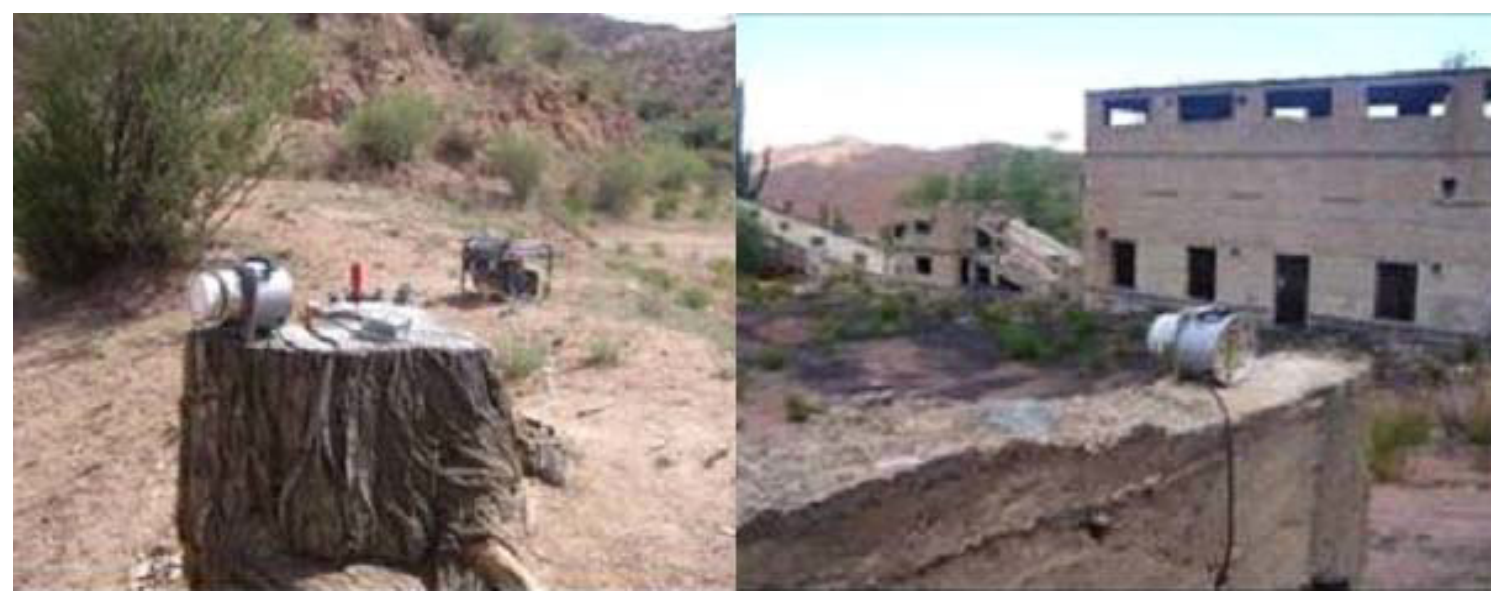

Picture 11. Sampling of aerosols in the air on the territory of the former industrial zone Kaji-Sai

\subsection{Alpha and Beta Activity Concentration ${ }^{238} \mathrm{U},{ }^{226} \mathrm{Ra}-$ in an Aqueous Medium}

Alpha and beta activity. In accordance with the sanitary standards 2.1.4.002-03 reference levels for alpha emitters drinking water was $0,1 \mathrm{~Bq} / \mathrm{l}$, beta emitters $-1 \mathrm{~Bq} / 1$. Results of analyzes of samples from the water of the Issyk-Kul region showed the total alpha-activity levels varied in the range of $0,10-0,25 \mathrm{~Bq} / 1$ beta activity of $0,06-0,13 \mathrm{~Bq} / 1$, which was within the normal range (Table. 7).

The average level of radioactivity was alpha activity $0,6-$ $1,8 \mathrm{~Bq} / \mathrm{kg}$ and beta activity $0,4-1,0 \mathrm{~Bq} / \mathrm{kg}$ in the water of the lake. It should be noted that the level of alpha activity is higher from 2 to 7 times, and the beta activity 2 to 6 times in the water of the lake than the river.

In the area of man-made sites of water samples were taken for analysis of the radiation from the streams that run through the area of uranium tailings Kaji-Say and flow down towards the lake. Measurements were carried out by methods of low-background liquid scintillation spectrometry after appropriate radiochemical cleaning of the samples (tab. 8).

Table 8 . The alpha activity was $234+238 \mathrm{UBq} / 1$ in the water of the streams in the sediment 1-2, the comparison with water of the lake (areas of Cholpon-Ata, Ak-Terek), it was higher from 7 to 18 times and the total alpha activity $\mathrm{Bq} / 1$ from 5 to 12 times. It is known that the background uranium concentration was high enough (about $1 \mathrm{~Bq} / \mathrm{l})$ in the water of Lake Issyk-Kul. Therefore, the drains contaminated water from the tailings pond location area virtually no effect on the pollution, even closely spaced recreation areas. Their influence also extends to the main resort area of the region the northern coast of Lake Issyk-Kul. We had studied the concentration of radon-222 in the soil cover in the coastal areas of the lake Issyk-Kul (Table 9, Picture 7).

The level of the permissible concentration of radon and the level of the background were low in the upper layer of soil of the coastal areas, but there were small increase in the area of the hot thermal springs - the village Oruktu $-24,24+/-2.2$ $\mathrm{MBq} /\left(\mathrm{m}^{2} \times \mathrm{s}\right)$, the village of Bar-Bulak- $28,48+/-2,6$ $\mathrm{mBq} /\left(\mathrm{m}^{2} \times \mathrm{s}\right)$ and Biological station - 30,61 +/- 3,2
$\mathrm{mBq} /\left(\mathrm{m}^{2} \times \mathrm{s}\right)$. There were the same level of radon in the area of the villages of Kaji-Sai, Jenish and Ak-Terek.

It is known that the average annual equivalent equilibrium volume activity of radon isotopes should not exceed 200 $\mathrm{Bq} / \mathrm{m}^{3}$ (RSS-96, RSS-99) in indoor air. For example, in the US, where typical soil radon content $7,4-74 \mathrm{mBq}$ per liter $/\left(\mathrm{m}^{2} \times \mathrm{s}\right)$.

Atmospheric air. Measurements were conducted the volume concentration of radon and decay products in the air; selected air samples for the measurement to determine the concentration of alpha-active aerosols over the tailings and in other areas in the province (Picture 11).

According to the results of our analysis of the concentration of alpha-active aerosols in the air were observed significantly by the differences of the territory of uranium industrial area, in the village Kaji-Sai, and the recreational area of the northern coast of the lake Issyk-Kul (Tab. 10).

The main contribution is to form ${ }^{210} \mathrm{~Pb}$ and ${ }^{210} \mathrm{Po}$ the inhalation radiation dose. However, the levels of activity in the region to match the natural background of the province $\left(0,5-1,0 \mathrm{mBq} / \mathrm{m}^{3}\right)$. Proof of this were identified relatively low flows of radon exhalation on the surface of the tailings $\left(0,03-0,40 \mathrm{~Bq} / \mathrm{m}^{2} \times \mathrm{s}\right)$. This indicates that the coating tailings reliably prevent the spread of radium exhalation, and the main source of alpha-dusting is active aerosols contaminated soil and ash, which were currently mainly covered with clean soil. The flows of the radon exhalation $6,2+/-1,9 \mathrm{mBq} / \mathrm{m}^{2} \times \mathrm{s}$ were measured in some local areas of the industrial zone, adjacent to the tailings (the area up to $1 \mathrm{~m} \mathrm{2}$ ). At such sites additional remediation and restore primer should be conducted.

\section{Conclusions}

1. There was conducted radiometric survey of the soil from the biosphere reserve, the coastal zone of lake Issyk-Kul, where the level of background radiation was relatively low (15 to $40 \mathrm{mR} / \mathrm{h}$ ). 
2. From the results of the research, the gamma radiation dose was $30-60 \mathrm{mR} / \mathrm{h}$ on the surface of the tailings capacity in the natural and technogenic uranium site of Kaji-Sai and in areas with abnormally high levels of exposure dose was 600 $1500 \mathrm{mR} / \mathrm{h}$ in broken covers of the protective layer.

3. The minor variations of the natural background radiations were established in different types of soil Issyk-Kul region, perhaps this is due to the inhomogeneous distribution of natural radionuclide, scattered in the soil and rocks of the earth. The total radioactivity $\left({ }^{238} \mathrm{U},{ }^{234} \mathrm{U},{ }^{228} \mathrm{Th}\right.$, ${ }^{228} \mathrm{Ra},{ }^{230} \mathrm{Th},{ }^{210} \mathrm{~Pb},{ }^{226} \mathrm{Ra}$ ) of soil was an average at the level of the background nearby the tailing of Kaji-Sai.

4. The Alpha activity level was $(0,6-1,8 \mathrm{~Bq} / \mathrm{l})$ higher in the water of the lake than the river from 2 to 7 times and at beta activity $(0,4-1,0 \mathrm{~Bq} / \mathrm{l})$ was from 2 to 6 times.

5. The activity of the main dose-isotopes in the air $-{ }^{210} \mathrm{~Pb}$ and ${ }^{210} \mathrm{Po}$ of the province corresponds to the natural backdrop for this region $\left(0,5-1,0 \mathrm{mBq} / \mathrm{m}^{3}\right)$. The level of ${ }^{222} \mathrm{Rn}$ was low in the permissible concentrations in the coastal areas of the lake and there was a slight increase in the area of hot springs and wetlands.

\section{REFERENCES}

[1] Bykovchenko Y.G. Man-caused pollution of the biosphere uranium Kyrgyzstan. - B., 2005. - 169 p.

[2] Vasiliev I.A. Assessment of environmental hazard radioactive waste // Radiological and related problems of uranium production. - B., 2008 - B, 5. - P.101-103.

[3] Vorotnitsky I.E. The biogenic migration of uranium in the lake Issyk-Kul. Author. diss.cand. biol. sciences. - M.: Moscow State University, 1988. - 17 p.

[4] Djenbaev B.M., Mursaliyev A.M. Biogeochemistry of natural and man-made ecosystems of Kyrgyzstan. - B.: Ilim, 2012. $404 \mathrm{p}$.

[5] Djenbaev B.M., Kaldybaev B.K., Zholboldiev B.T. Problems of radioecology and radiation safety of former uranium industries in Kyrgyzstan // Radiation Biology. Radioecology. - 2013. - T.53, number 4. - P.428-431.

[6] Djenbaev B.M., Zholboldiev B.T., Kaldybaev B.K. The current state of the Issyk-Kul province uranium radiobiogeochemical // Radiation Biology. Radioecology. 2013. - T.53, number 4. - P.432-440.

[7] Djenbaev B.M., Kaldybaev B., Toktoeva T., Kenjebaeva A. Radiobiogeochemical Assessment of the Soil Near the Issyk-kul Region // Journal of Geological Resource and Engineering (USA) 1 (2016) p.39-43.

[8] Kaldybaev B.K., Djenbaev B.M. Radiological studies of coastal biosphere territory "Issyk-Kul". Ecology and Biogeochemistry biosphere. Lap Lambert Academic Publishing, Germany 2015. p.122.

[9] Karpachev B.M., Mengs.V. Radiation-ecological research in Kyrgyzstan - B., 2000. - 56 p.

[10] Kowalski V. Geochemical ecology: Essay / V.V.Kovalsky. M.: Nauka, 1974 - 300 p.

[11] Kowalski V.V., Vorotnitsky I.E., Lecarev V.C.and other. Uranium biogeochemical food chains in the conditions of the Issyk-Kul basin // Proceedings of the biogeochemical laboratory - M.: Nauka, 1968. - T.XII. - P.25-53.

[12] Torgoev I.A., Aleshin Y.G. Ecology and waste mining in Kyrgyzstan. -B.: Ilim, 2009. - 240 p.

[13] Tynybekov A.K., Hamby D.M. Radiological characterization of the southern coast of the lake Issyk-Kul. Sb.tr. Inst of Management, Business and Tourism. - 1999. - Issue 2. P.9-17.

[14] Radiation protection and safety of radiation sources: international basic safety standards. - Vienna: International Atomic Energy Agency, No. GSR Part 3, 2014. - P.1-16.

[15] Murray A.S., Marten R., Johnson A. Analysis of naturally occurring radionuclide of environmental concentrations by gamma spectrometry // J. Radioanal and. Nucl. Chem. - 1987. - Vol.115, № 2. - P.263-288.

[16] Djenbaev B.M., Zholboldiev B.T. Intercalibration Canberra gamma spectrometry laboratory biogeochemistry of BPI NAS KR // Math. National Academy of Sciences of the Kyrgyz Republic. - 2014. - №1. - P.23-28.

[17] Bakhur A.E., Malyshev V.I., Manuylova L.I. Preparation of natural water samples for the measurement of total alpha and beta - activity: method. Recommended. - M.: NPP "Doza", 1997. $-23 \mathrm{p}$.

[18] Dimova N., Burnett W.C., Lane-Smith D. Improved automated analysis of radon (222Rn) and thoron (220Rn) in natural waters. Environ Sci Technol 43:8599-8603. - P. 22-26. 